Provided for non-commercial research and education use. Not for reproduction, distribution or commercial use.

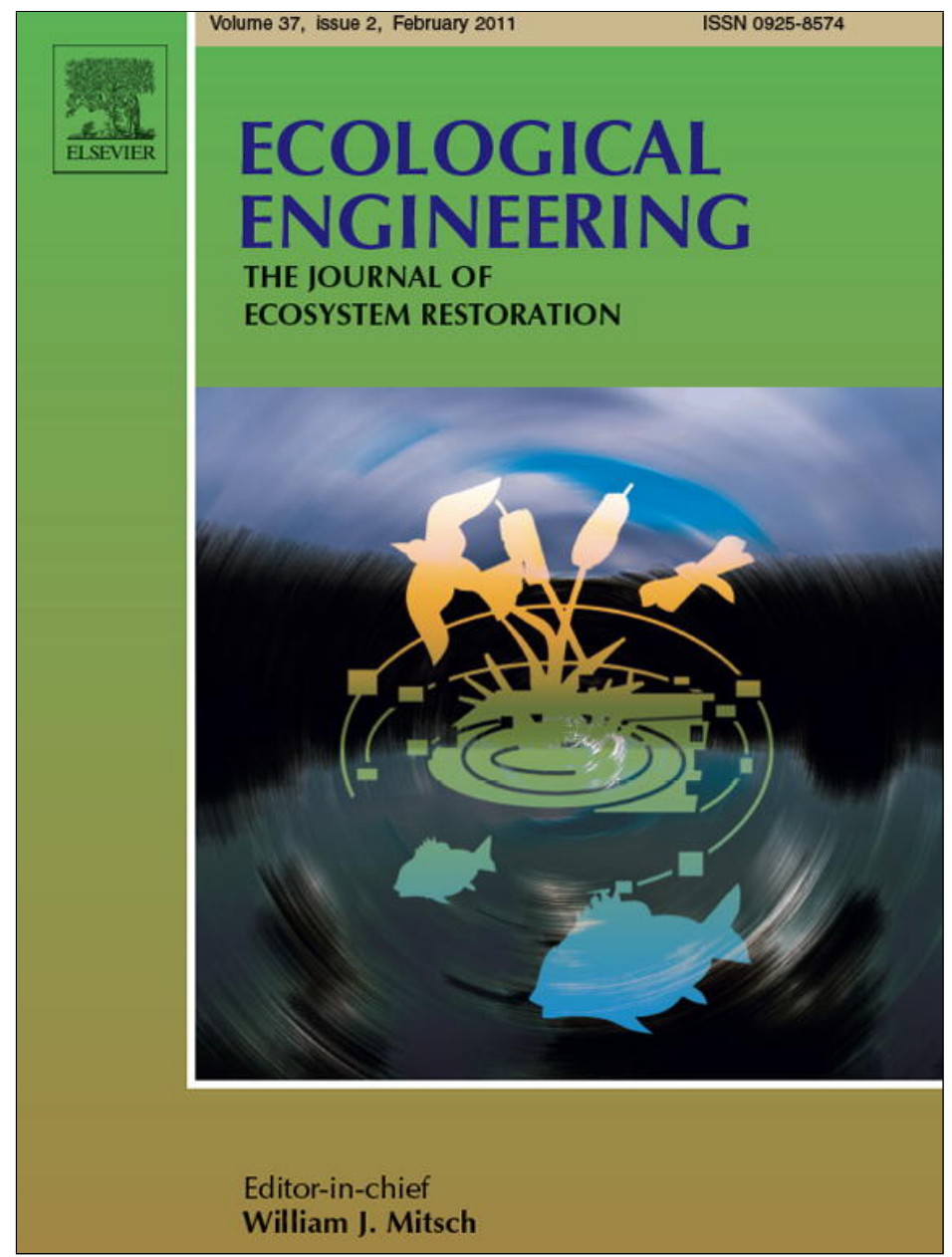

(This is a sample cover image for this issue. The actual cover is not yet available at this time.)

This article appeared in a journal published by Elsevier. The attached copy is furnished to the author for internal non-commercial research and education use, including for instruction at the authors institution and sharing with colleagues.

Other uses, including reproduction and distribution, or selling or licensing copies, or posting to personal, institutional or third party websites are prohibited.

In most cases authors are permitted to post their version of the article (e.g. in Word or Tex form) to their personal website or institutional repository. Authors requiring further information regarding Elsevier's archiving and manuscript policies are encouraged to visit:

http://www.elsevier.com/copyright 


\title{
Buffer strip width and agricultural pesticide contamination in Danish lowland streams: Implications for stream and riparian management
}

\author{
Jes J. Rasmussen ${ }^{\mathrm{a}, *}$, Annette Baattrup-Pedersen ${ }^{\mathrm{a}}$, Peter Wiberg-Larsen ${ }^{\mathrm{a}}$, Ursula S. McKnight ${ }^{\mathrm{b}}$, \\ Brian Kronvang ${ }^{a}$ \\ a Department of Freshwater Ecology, National Environmental Research Institute, Aarhus University, Vejlsøvej 25, 8600 Silkeborg, Denmark \\ ${ }^{\mathrm{b}}$ Department of Environmental Engineering, Technical University of Denmark, Miljøvej, Building 113, 2800 Kgs. Lyngby, Denmark
}

\section{A R T I C L E I N F O}

\section{Article history:}

Received 10 June 2011

Received in revised form 26 July 2011

Accepted 7 August 2011

\section{Keywords:}

Buffer strip

Pesticides

Runoff

Water framework directive

Non-point sources

\begin{abstract}
A B S T R A C T
According to the European Water Framework Directive, member states are obliged to ensure that all surface water bodies achieve at least good ecological status and to identify major anthropogenic stressors. Non-point source contamination of agricultural pesticides is widely acknowledged as one of the most important anthropogenic stressors in stream ecosystems.

We surveyed the occurrence of 31 pesticides and evaluated their potential toxicity for benthic macroinvertebrates using Toxic Units (TU) in 14 Danish 1st-and 2nd-order streams in bed sediments and stream water during storm flow and base flow. Total pesticide concentrations and toxic potential were highest during storm flow events with maximum TU ranging from -6.63 to -1.72 . We found that minimum buffer strip width in the near upstream area was the most important parameter governing TU. Furthermore, adding a function for minimum buffer strip width to the Runoff Potential (RP) model increased its power to predict measured TUs from $46 \%$ to $64 \%$. However, including a function for tile drainage capacity is probably equally important and should be considered in future research in order to further optimise the RP model. Our results clearly emphasise the importance of considering buffer strips as risk mitigation tools in terms of non-point source pesticide contamination. We furthermore apply our results for discussing the minimum dimensions that vegetated buffer strips should have in order to sufficiently protect stream ecosystems from pesticide contamination and maintain good ecological status.
\end{abstract}

(C) 2011 Elsevier B.V. All rights reserved.

\section{Introduction}

Non-point source contamination of streams with pesticides applied in agricultural production is widely acknowledged as one of the greatest stressors to stream ecosystems, and various routes for pesticide transport from the field to stream recipients have been identified (Neumann et al., 2002; Schulz, 2004). There is a clear consensus in the existing literature verifying surface runoff and flow through tile-drains as the most important pathways for nonpoint pesticide losses in agricultural catchments (Kreuger, 1998; Kronvang et al., 2004; Neumann et al., 2002; Wauchope, 1978). As a consequence, the highest pesticide concentrations occur during heavy precipitation events, and the footprint of pesticides is proposed to be more distinct in small streams due to a closer connectivity between land and stream (Kreuger and Brink, 1988; Probst et al., 2005; Schulz, 2004).

\footnotetext{
* Corresponding author. Tel.: +45 89201757.

E-mail address: jr@dmu.dk (J.J. Rasmussen).
}

According to the European Water Framework Directive (WFD), member states are obliged to measure and ensure that all surface water bodies achieve at least good ecological status within a defined timetable (European Commission, 2000). Requirements are not only to assess the overall ecological quality of surface waters, but also to identify the major environmental and/or anthropogenic drivers of ecological degradation and the extent of impairment. Several biotic indices and multi-metric procedures have been developed attempting to robustly characterise the impact of selected stressors that result in the deviation from good ecological status (Furse et al., 2006).

Non-point source pesticide contamination of rivers potentially poses a threat to all stream dwelling organisms (Liess et al., 2005), and there is a growing interest to develop and provide field-based models to assist in characterising the non-point source pesticide contamination that originates from agricultural practices (Friberg et al., 2003; Schäfer et al., 2007, 2011a; Schulz, 2004). However, there is still a need for additional studies that investigate the loss, occurrence and fate of agricultural pesticides in streams and their impact on stream biota. Establishing causal relationships between 
pesticides and their impact on flora and fauna is difficult due to natural variability in stream ecosystem communities and the co-existing pressures from several other anthropogenic stressors (Liess et al., 2005; Rasmussen et al., 2011). However, Liess and von der Ohe (2005) introduced the SPEcies At Risk indicator for pesticides ( $S P E A R_{\text {pesticides }}$ ), which has been validated as a selective indicator that successfully separates the effects of pesticides from those of other anthropogenic stressors (Schäfer et al., 2007, 2011a). Furthermore, Schriever et al. (2007b) found that SPEAR pesticides was the biological parameter best describing stream macroinvertebrate community responses to a modelled indicator of pesticide surface runoff (RP). In contrast, Rasmussen et al. (2011) were unable to

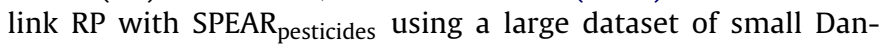
ish streams, which could be due to the presence of wider buffer strips along Danish streams compared to German streams. Since buffer strip information is not integrated into the RP model but is known to significantly influence pesticide runoff, different buffer strip characteristics between the two sets of study streams can plausibly explain the different results. Implementing a function for buffer strip width (representing a simplified measure for pesticide runoff retaining capacity) might, therefore, significantly improve the predictive power of the RP model.

In this study we screened 14 Danish 1st-and 2nd-order streams for pesticides that are frequently applied in normal agricultural practices in their respective catchments. The study aims were to (1) characterise pesticide occurrence and potential toxicity for benthic macroinvertebrates in Danish streams, (2) identify the environmental parameters that most strongly govern pesticide occurrence and toxicity, and (3) improve the predictive power of the RP model by using detailed environmental data and by adding a function for buffer strip width.

\section{Materials and methods}

\subsection{Study area}

The field campaign was conducted in 2009 in a set of study streams that is located on Funen, Denmark (Fig. 1), where catchments are characterised by low elevation and loamy soils with medium to low infiltration capacity. Agriculture and forest are the dominant types of land use. Climatic conditions are temperate and the average regional precipitation is $700 \mathrm{~mm}$ year $^{-1}$. Dominating crop types in the studied catchments were rye, wheat, barley, grass and oilseed rape (Appendix A).

\subsection{Stream characteristics}

Fourteen 1st-or 2nd-order streams were selected based on the following selection criteria: year-round water flow, no maintenance activities conducted during the sampling period (dredging and weed-cutting) and no sources of pollution other than from agricultural non-point sources. The streams represent a gradient of potential pesticide contamination predicted from the proportion of adjacent agricultural land. In order to optimise the selection of streams, the pesticide runoff was predicted by applying the runoff potential (RP) model (see also Schriever et al., 2007a,b). The RPmodel is a generic indicator that was developed to quantify the risk of pesticide runoff contamination to streams from agricultural land (Schriever et al., 2007a). Calculated RP for site selection support was based on the assumption that any runoff-triggering precipitation event would be evenly distributed among the studied streams. Data input for grown crops and pesticide application was based on 2008 data (Danish EPA, 2009).
Using aerial photographs, buffer strip dimensions (minimum and average buffer strip width) were determined for each stream by digitalising buffer strips in 500, 1000 and $2000 \mathrm{~m}$ sections upstream of the sampling sites in ArcGis 9.2. Average buffer strip width was calculated by simple mathematical integration of the digitalised buffer strip area. The outer boundaries of buffer strips were characteristically visible using summer photos, since buffer strips are relatively unmaintained compared to conventional agricultural fields and fallow land. Consequently, the different types of vegetation found in the buffer strips clearly defined their outer boundaries.

\subsection{Quantification of pesticide contamination}

The selection of analysed pesticides was based on application frequency and total applied amounts in 2008 (Danish EPA, 2009). This list was augmented with a series of banned pesticides that are commonly found in drinking water wells. In total, 19 herbicides, 6 fungicides and 6 insecticides were included in the sampling program (Appendix B). The sampling campaign was conducted in 2009.

We used event-triggered samplers to characterise pesticide contamination during heavy precipitation events (Liess and von der Ohe, 2005). The sampling system consisted of two $1 \mathrm{~L}$ glass bottles that were deployed in the flowing part of the stream channel. Bottles were filled passively through small $(0.5 \mathrm{~cm}$ in diameter) glass tubes when the water level increased above the glass tube opening. The two bottles were positioned $5 \mathrm{~cm}$ and $10 \mathrm{~cm}$ above base flow water level, respectively. Filled water samples were retrieved within $24 \mathrm{~h}$ after each heavy precipitation event. During the sampling period, two precipitation episodes triggered the sampling system. The first episode occurred on the 28th of May and was characterised by a precipitation depth ranging from $7 \mathrm{~mm}$ to $10 \mathrm{~mm}$ depending on the site. This episode triggered samplers in only six streams. The second episode occurred on the 12th of June and was characterised by a precipitation depth ranging from 19 to $47 \mathrm{~mm}$. The latter triggered the sampling system in all streams.

Bed sediment was sampled (stratified sampling) on the 20th of July using a kajak corer ( $8 \mathrm{~cm}$ diameter). All sediment samples were collected within a $50 \mathrm{~m}$ stream section extending upstream from the event triggered samplers. One sample consisted of a minimum of 30 sub-samples from the top layer $(1-2 \mathrm{~cm})$ of newly deposited sediment at in order to obtain sediment samples that generally were representative for the respective reaches (see also Friberg et al., 2003).

Water samples were collected manually in August during low flow conditions in order to characterise the potential 'background input' of pesticides originating from groundwater inflow. Banned pesticides were detected in all streams indicating the importance of groundwater input as a source of pesticides. However, in our study, pesticides in the August samples were characterised by a combination of low concentrations and low toxicity to benthic macroinvertebrates. Consequently, we assumed that pesticides originating from groundwater input were of minor importance in the studied streams.

The pesticide analyses (including solid phase extraction) were conducted by OMEGAM laboratories in Amsterdam; unfiltered samples were sent to the laboratories in coolers immediately after collection. The final extract of each sample was used in different analysis programs. Analysis programs were based on gas-chromatography mass-spectrometry (GC-MS) or liquid-chromatography mass-spectrometry (LC-MS). The limit of quantification for each compound was determined as the lowest concentration that can be reliably quantified ( $95 \%$ confidence interval) (Appendix B). Detection limits were $0.01-0.1 \mu \mathrm{g} \mathrm{L}^{-1}$ for water 


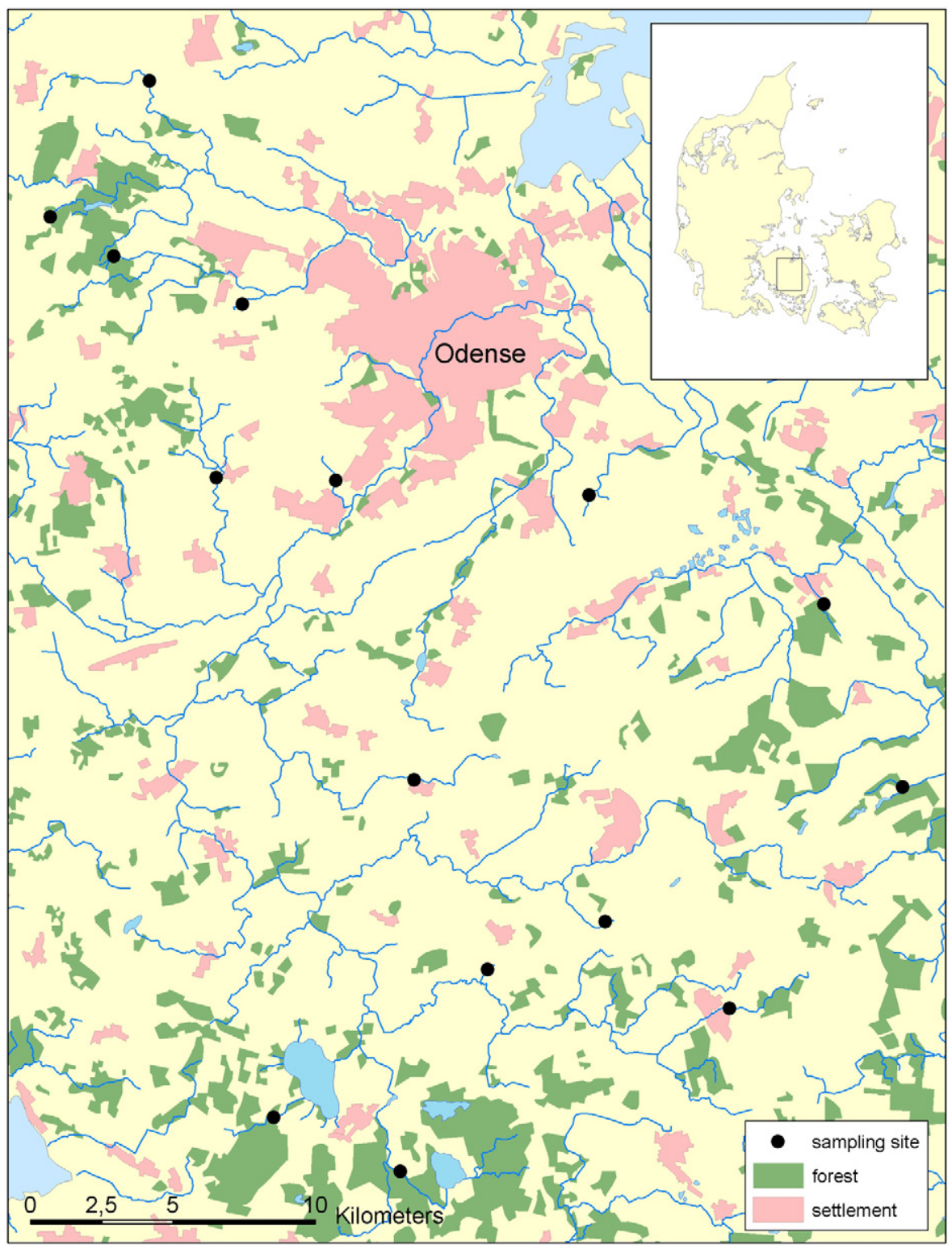

Fig. 1. Schematic map of the 14 study stream locations.

samples and $0.01-0.1 \mathrm{mg} \mathrm{kg}^{-1}$ (dry weight) for sediment samples. Results were corrected for recovery, which was determined by spiked samples. For all compounds, recovery was reported to be within $85-110 \%$ of actual concentrations.

\subsection{Predicted pesticide exposure}

The runoff potential model was produced to predict runoff contamination of a generic compound instead of predicting actual runoff losses for a specific compound. However, due to the high resolution and quality input data (field block-specific crop data) we were able to meet data requirements for a more detailed version of the model in terms of grown crops (Eq. (1)). Due to the high resolution of crop data, we could additionally improve our estimates for pesticide application rates using the average compound-specific application rate for each crop type in 2009 (Danish EPA, 2010). Thus, we could calculate the runoff potential for the compounds associated with each crop type instead of just predicting runoff for a generic compound. For further details on the original RP model, consult Schriever et al. (2007a). We calculated RP for all sites applying a two-sided corridor of $100 \mathrm{~m}$ extending $500 \mathrm{~m}$ upstream of the sampling location. Modification of the considered catchment size, i.e. implementation of other corridor lengths ( 1000 or $2000 \mathrm{~m}$ ) or utilisation of the total catchment had no significant effect on the results. For convenience the two-sided $100 \mathrm{~m}$ corridor extending $500 \mathrm{~m}$ upstream will be referred to as the stream corridor. We calculated pesticide runoff by first applying the runoff model underlying the RP (modified after Schriever et al. (2007a)):

$$
\begin{aligned}
\operatorname{gLOAD}= & \sum_{i=1}^{n} \sum_{j=1}^{m} \sum_{l=1}^{k} A_{i, j} \cdot D_{l} \cdot\left(1-\frac{I_{j}}{100}\right) \cdot \frac{1}{1+\mathrm{Koc}_{l} \cdot \mathrm{OC}_{i} / 100} \\
& f\left(s_{i}\right) \cdot \frac{f\left(P_{i}, T_{i}\right)}{P_{i}}
\end{aligned}
$$

where index $i$ refers to the respective field blocks, index $j$ refers to different crop types present on the fields, and index $l$ refers to specific pesticides. $A_{i, j}$ is the size of agricultural land (ha), $D_{l}$ is 
Table 1

Pesticides detected in stream water from 14 Danish streams in the period from April to August, 2009. Three samples were collected in each stream of which two were collected with event-triggered samplers during May and June (high precipitation events), and one sample was collected manually during base-flow conditions in August. Pesticide groups are indicated by letters H, F and I representing herbicides, fungicides and insecticides, respectively.

\begin{tabular}{|c|c|c|c|c|}
\hline Compound & Min concentration $\left(\mu \mathrm{gL}^{-1}\right)$ & Max concentration $\left(\mu \mathrm{g} \mathrm{L}^{-1}\right)$ & Highest TU & Detection frequency (\%) \\
\hline Desethylterbutylazine $(\mathrm{H})$ & 0.01 & 0.11 & -4.65 & 100 \\
\hline Atrazine $(\mathrm{H})$ & 0.01 & 0.02 & -6.63 & 7 \\
\hline Dimethoate (I) & 0.01 & 0.18 & -4.05 & 14 \\
\hline Metachlor $(\mathrm{H})$ & 0.01 & 0.05 & -5.82 & 57 \\
\hline Diflufenican $(\mathrm{H})$ & 0.02 & 0.15 & -3.20 & 29 \\
\hline Metamitron $(\mathrm{H})$ & 0.12 & 0.12 & -4.68 & 7 \\
\hline Pendimethaline $(\mathrm{H})$ & 0.02 & 0.97 & -2.46 & 14 \\
\hline Aclinofen $(\mathrm{H})$ & 0.14 & 0.14 & -3.93 & 7 \\
\hline Propyzamide $(\mathrm{H})$ & 0.01 & 0.43 & -4.11 & 21 \\
\hline Prosulfocarb $(\mathrm{H})$ & 0.01 & 0.07 & -3.86 & 21 \\
\hline Terbutylazine $(\mathrm{H})$ & 0.01 & 0.6 & -4.55 & 57 \\
\hline Hexazinone $(\mathrm{H})$ & 0.06 & 0.06 & -6.15 & 7 \\
\hline Simazine $(\mathrm{H})$ & 0.03 & 0.03 & -4.56 & 7 \\
\hline $\operatorname{DEET}(\mathrm{H})$ & 0.05 & 0.05 & -6.18 & 7 \\
\hline Boscalid (F) & 0.07 & 0.72 & -3.87 & 36 \\
\hline Azoxystrobin (F) & 0.05 & 0.51 & -2.77 & 43 \\
\hline Propiconazole $(\mathrm{F})$ & 0.04 & 0.27 & -4.58 & 43 \\
\hline Tebuconazole (F) & 0.02 & 0.24 & -4.24 & 50 \\
\hline Dimethomorf (F) & 0.01 & 0.08 & -5.12 & 14 \\
\hline Pirimicarb (I) & 0.01 & 0.32 & -1.72 & 21 \\
\hline
\end{tabular}

a Based on LC50 values for $48 \mathrm{~h}$ acute toxicity tests with Daphnia magna (Tomlin, 2001).

the application rate of the pesticide compound, $I_{j}$ is the crop- and growth phase-specific plant interception of the substance at the time of the precipitation event (\%), $\mathrm{Koc}_{l}$ is the organic carbon sorption coefficient of the pesticide compound, $\mathrm{OC}_{i}$ is the soil organic carbon content of a field patch (\%), $s_{i}$ is the mean slope of a field (\%), $f\left(s_{i}\right)$ describes the influence of the field slope. $P_{i}$ is the precipitation depth $(\mathrm{mm})$ of the considered event, $T_{i}$ refers to the soil texture of a field (sandy/loamy), $f\left(P_{i}, T_{i}\right)$ is a function describing the surface runoff volume for vegetated soils in the middle or late period for vegetation growth. RP (Eq. (2)) is then calculated as:

$R P=\log \left(\max _{i=1}^{n}\left(g \operatorname{LOAD}_{i}\right)\right)$

The runoff potential model was parameterised as follows: fieldspecific crop types for each field block in the stream corridor were extracted from a national Danish database (LOOP) (Grant et al., 2006). Soil slope in the stream corridor was estimated using a Digitalised Elevation Map (DEM) with $1.6 \mathrm{~m}$ resolution in ArcGis 9.2. Soil texture composition (including humus content) within the stream corridor was extracted from the Hair database (Greve et al., 2007). According to Thomas and Goudie (2000), sandy soil was defined as soils containing $<10 \%$ clay and $>85 \%$ sand. The relative organic carbon content of soils was calculated as $57 \%$ of the humus content (Thomas and Goudie, 2000). The average crop-specific application rate for each pesticide compound potentially applied in 2009 was extracted from national pesticide statistics (Danish EPA, 2010). Precipitation data were provided by the Danish Meteorological Institute (http://www.dmi.dk) (100 $\mathrm{km}^{2}$ resolution). The daily recorded precipitation was assumed to result from a single precipitation event. Plant interception values $\left(I_{j}\right)$ were assigned to all crop types that were present during the considered precipitation event according to Linders et al. (2000).

\subsection{Data analysis}

We applied toxic units (TU) as a measure for pesticide toxicity, calculating TU for all pesticides detected in each sample. TU values are based on the acute $48 \mathrm{~h}$ LC50 value for Daphnia magna, as given in Tomlin (2001) (Eq. (3)).

$T U_{(\text {D.magna })}=\log \left(\frac{C_{i}}{\mathrm{LC} 0_{i}}\right)$

where $\mathrm{TU}_{(D \text {.magna })}$ is the toxic unit for pesticide $i, C_{i}$ is the measured concentration of pesticide $i$ and $\mathrm{LC}^{2} \mathrm{O}_{i}$ is the corresponding $48 \mathrm{~h}$ LC50 value for $D$. magna exposed to pesticide $i$. We identified the maximum TU for each water sample, and additionally calculated the summed TU for all pesticides in each water sample. The summation of all TUs is based on the assumption that all compounds act under the principle of toxic additivity. As the number of components in a toxic mixture increases, the range of deviation from toxic additivity is proposed to decrease (the Funnel hypothesis) (Warne and Hawker, 1995).

All environmental parameters considered (minimum and average buffer strip width, proportion of agriculture in the stream corridor, crop types, estimated pesticide application, field slopes and soil texture) were then correlated to the summed TU, maximum TU, number of pesticides and sum concentration of pesticides using Spearman rank order $(r)$ correlations $(P<0.05)$. All tests were performed using the software SAS enterprise guide 4.2. Leverage and Cook's Distance were calculated for all fitted regressions in order to evaluate the contributed weight of each data point. No values for Cook's Distance exceeded 0.1 and no leverage values were greater than $2^{*}(p / n)$, where $p$ is the number of parameters in the model including the intercept, and $n$ is the total number of observations. $R^{2}$ values are given for all presented regressions.

In addition, we attempted to improve the RP model by implementing various functions of minimum and average buffer strip width in the stream corridor. A fitted regression of the modified RP model as a function of calculated TUs was compared to that of the original RP model using Analysis of Covariance (ANCOVA) $(P<0.05)$ in SAS 9.2.

\section{Results}

\subsection{Pesticides and $T U$}

The results of the field campaign disclosed a total of 13 herbicides, 5 fungicides and 2 insecticide that were actually detected in 

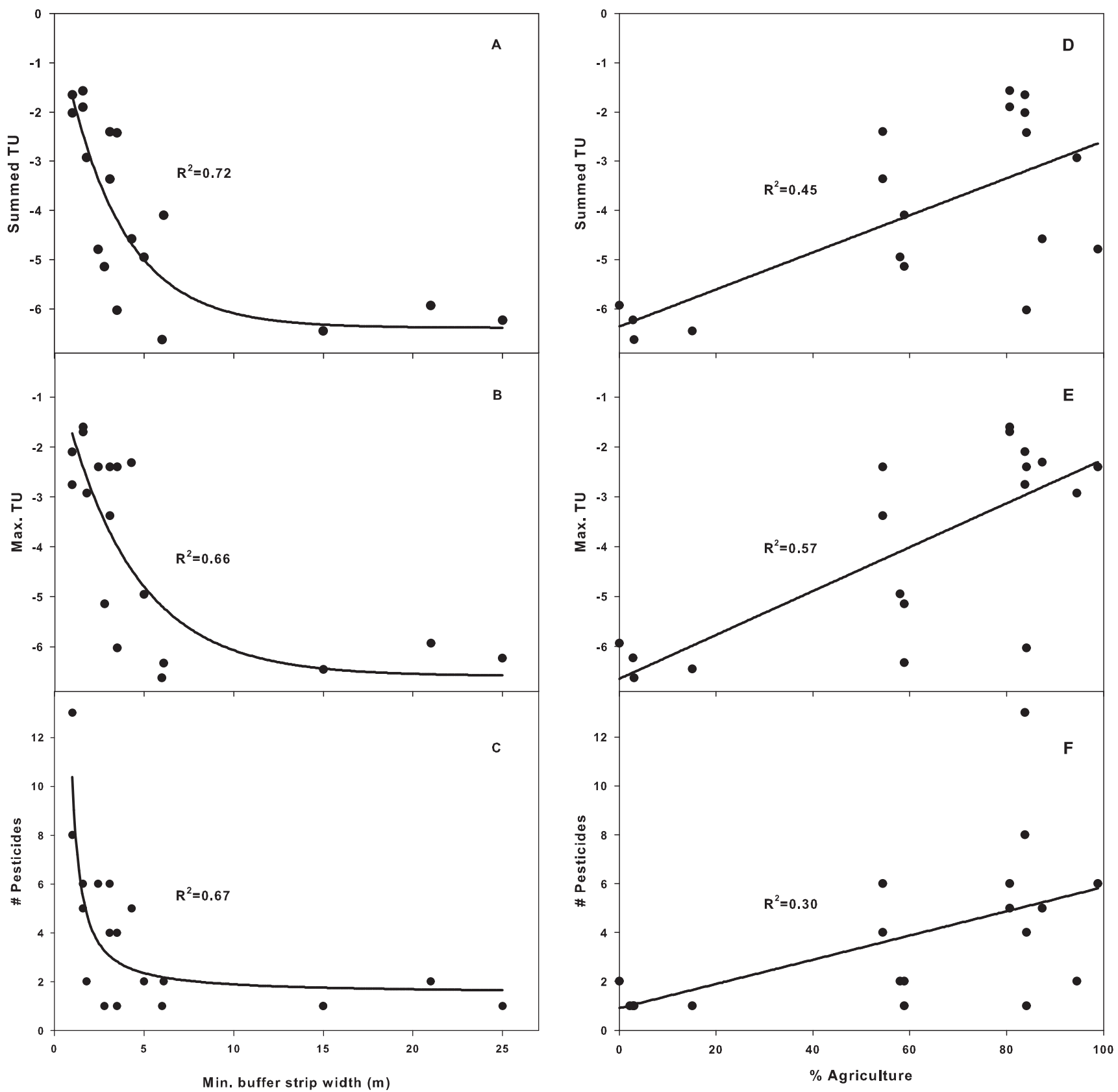

Fig. 2. The summed TU of all pesticides ( $A$ and $D$ ), the maximum TU (B and $E$ ) and the total number of pesticides ( $C$ and $F$ ) as a function for minimum buffer strip width and the proportion of agricultural land (D, E and F, respectively). Presented data are based on water samples collected during storm flow conditions (two storm flow events) in 14 Danish streams in spring, 2009.

water samples from the 14 study streams (Table 1 ). Summed concentrations ranged from 0.01 to $3.17 \mu \mathrm{g} \mathrm{L}^{-1}$, the number of detected pesticides per sample ranged from 1 to 13 , maximum TU ranged from -6.63 to -1.72 , and summed TU ranged from -6.63 to -1.57 . In total, five of the nine streams at risk for receiving pesticide runoff (proportion of agricultural land $\geq 50 \%$ ) were characterised by at least one sample with summed and maximum TUs $\geq-3$. The carbamate insecticide Pirimicarb and the Strubilurine fungicide Azoxystrobin were the pesticides primarily responsible for the high TU values due to corresponding low $\mathrm{LC} \mathrm{O}_{(D \text {. magna) }}$ values. No pesticides were detected in the sediment samples.

Minimum buffer strip width was the environmental parameter most strongly correlated with summed TU and maximum TU $(r=0.80, P<0.0001$, Fig. 2a), followed by the proportion of agricultural land in the stream corridor $(r=0.48, P<0.05$, Fig. $2 d)$. Applying the maximum TU generated a comparable significant correlation with minimum buffer strip width $(r=0.78, P<0.0001$, Fig. 2b) and a slightly stronger significant correlation with the proportion of agriculture in the stream corridor $(r=0.66, P<0.01$, Fig. 2e). Applying the average buffer strip width generated a significant but weaker correlation with summed TU and maximum TU $(r=0.61, P<0.01$ and $r=0.65, P<0.01$, respectively) (data not shown). Furthermore, the number of pesticide compounds was significantly correlated to the minimum buffer strip width $(r=0.72, P<0.001$, Fig. $2 \mathrm{c})$ and the proportion of agricultural land in the stream corridor $(r=0.49, P<0.05$, Fig. 2f). Autocorrelations were found between the summed TU and the number of pesticides $(r=0.82, P<0.0001)$, as well as total pesticide concentration 


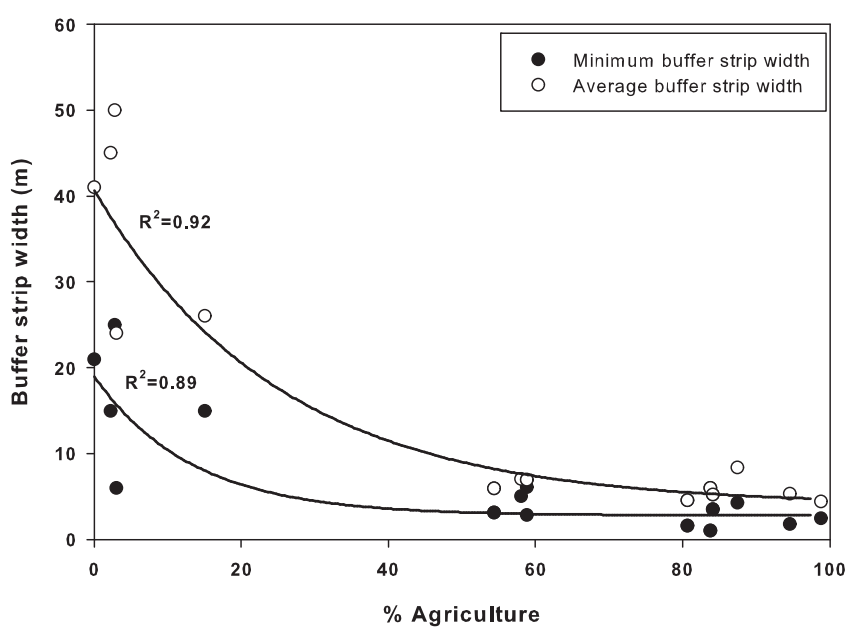

Fig. 3. Proportion of agricultural land as a function of minimum ( $)$ and average (○) buffer strip width. Data represent 14 Danish low-order streams.

$(r=0.71, P<0.001)$ (data not shown). Furthermore, total pesticide concentration was autocorrelated with the number of pesticides $(r=0.90, P<0.0001)$ (data not shown). The proportion of agricultural land was significantly correlated to minimum and average buffer strip width in the stream corridor $(r=0.66, P<0.01$ and $r=0.73, P<0.001$, respectively), as shown in Fig. 3. No correlation was found between estimated compound-specific applied amounts of pesticides in the stream corridor and in-stream concentrations of the respective compounds.

\subsection{Predicted pesticide exposure}

The runoff potential model (RP) was significantly correlated with the summed TU $(r=0.70, P<0.001$, Fig. $4 \mathrm{a})$ and the maximum TU $(r=0.63, P<0.01)$ (data not shown). Adding the inverse function for minimum buffer strip width (within a $2 \times 100 \mathrm{~m}$ stream corridor extending $500 \mathrm{~m}$ upstream from a sampling point) to the runoff model (underlying RP) by simple multiplication improved the significance of the correlation found between the RP and the summed TU $(r=0.83, P<0.0001$, Fig. $4 \mathrm{~b})$ and the maximum TU $(r=0.70, P<0.001)$ (data not shown), reflected by reduced data variability around the fitted regression. In other words, the explanatory power of the model increased from $46 \%$ to $64 \%$ by adding the inverse function for minimum buffer strip width to the RP model. Slope and intercept were not significantly different between the two regression lines $(P<0.05)$.

\section{Discussion}

\subsection{The influence of buffer strips on the occurrence of pesticides in streams}

Minimum buffer strip width within a two-sided $100 \mathrm{~m}$ stream corridor extending $500 \mathrm{~m}$ upstream from the pesticide sampling point was the environmental parameter most strongly correlated with summed and maximum TUs for pesticides in stream water during storm flow. Decreasing summed and maximum TUs with increasing minimum buffer strip width probably reflects runoff reduction, due especially to infiltration and pesticide adsorption to organic matter within the buffer strip (Anbumozhi et al., 2005; Lacas et al., 2005; Vidon et al., 2010). Minimum buffer strip width was autocorrelated with the proportion of agricultural land in the stream corridor and hence buffer strip width may act as a surrogate for the proportion of agricultural land. However, numerous site-specific studies document clear effects of buffer strips as a
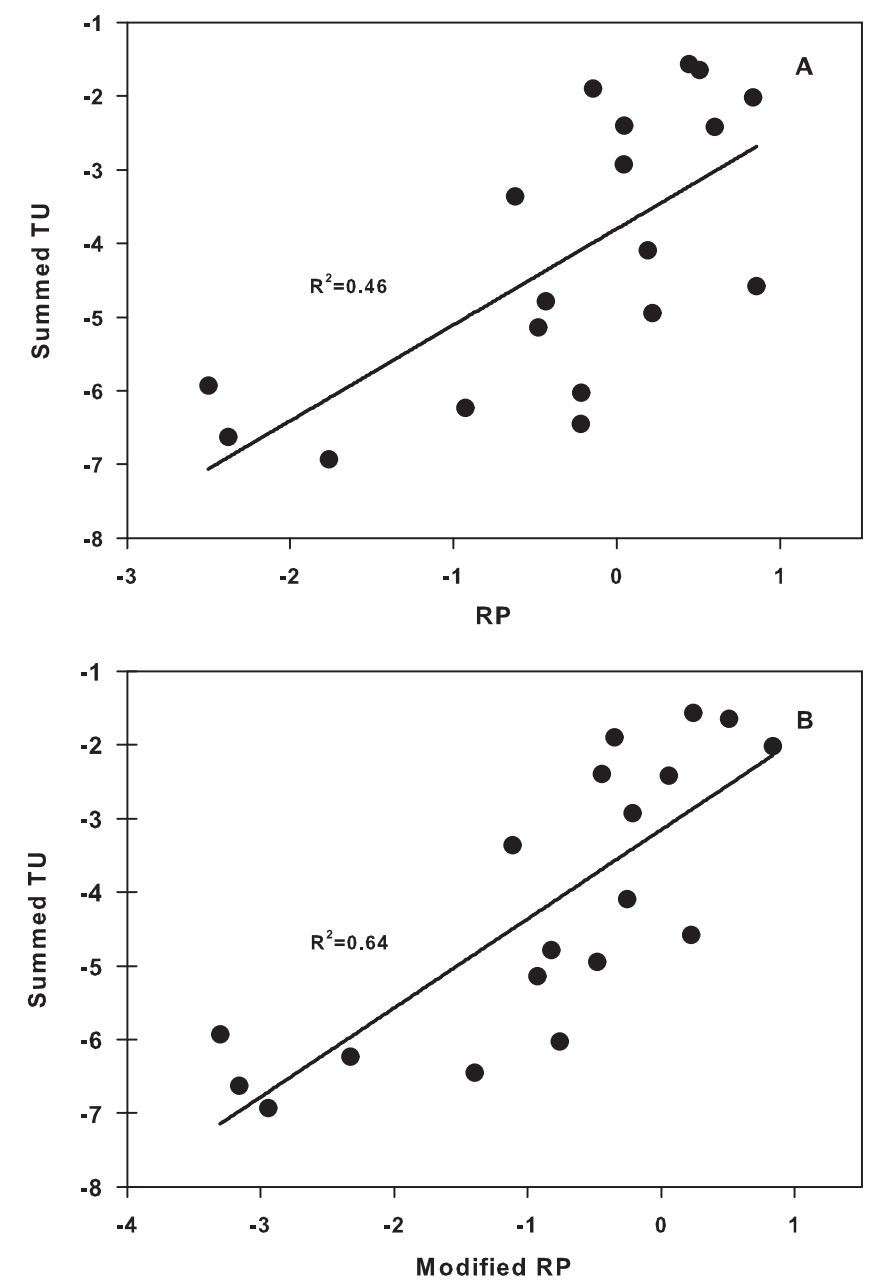

Fig. 4. The RP (A) and a modified version of RP (additionally considering minimum buffer strip width) (B) as a function for summed TU. The RP and modified RP were based on a series of environmental parameters deriving from a $2 \mathrm{~m} \times 100 \mathrm{~m}$ stream corridor extending $500 \mathrm{~m}$ upstream from the sampling points. Pesticide concentrations were measured during two storm flow events in 14 Danish low-land streams in spring, 2009.

useful tool for reducing pesticide transport from fields to stream recipients. For example, both Lacas et al. (2005) and Schriever et al. (2007a) found that precipitation intensity and local field characteristics (field slopes and crop types/growth phases) were more sensitive parameters than the proportion of agricultural land in the sub-catchments when predicting pesticide runoff. The strong correlations between minimum buffer strip width and TU measures (and pesticide concentrations) that were observed in this study, additionally suggest that the site properties only affected TU measures marginally. This probably reflects comparable siteand climatic- and agricultural (e.g. crop types and growth phases at the time of the storm events) properties in the region.

\subsection{Improving pesticide runoff predictability by adding buffer strip information}

Applying high-resolution data, the runoff potential (RP) model successfully predicted the toxicity of agricultural pesticides occurring in stream water during storm events. We found, however, that adding a function for the minimum buffer strip width - within a two-sided $100 \mathrm{~m}$ corridor extending $500 \mathrm{~m}$ upstream - to the RP model markedly improved the power of the model to predict summed TUs from $46 \%$ to $64 \%$ by reducing the data variability 
around the regression line. The slope and intercept of the regression line did not significantly change by adding the function for minimum buffer strip width to the RP model, which reflects that the overall correlation between the RP and summed TUs remains constant with or without buffer strip information. However, our results clearly emphasise that minimum buffer strip width should be added to the model whenever data are available, and furthermore underline the importance of considering buffer strip width in upstream environments of stream sites potentially at risk of being impacted by agricultural pesticides. Moreover, these findings lend support to Rasmussen et al. (2011) who were unable to confirm the correlation between the RP and SPEAR pesticides that was found by Schriever et al. (2007b) in German streams without buffer strips. Rasmussen et al. (2011) suggested that their results were probably confounded by the presence of buffer strips surrounding the study streams.

No data were available in terms of tile drainage intensity for the fields surrounding the streams that were examined in this study. However, loamy and clayey agricultural soils are often intensively tile drained, and the tile drains serve as a direct route for pesticides from field to surface waters underneath the buffer strip. Such sites have been found to be extremely vulnerable to pesticide loss, especially if macropores have developed in the soil (Kronvang et al., 2004; Lewan et al., 2009; Renaud and Brown, 2008). We therefore infer that incorporating information about tile drainage conditions in the considered (sub-) catchment would further improve the predictive power of the RP model.

\subsection{Pesticide characteristics and their potential ecological impact}

In this study, the summed toxic units (TU) based on storm flow water samples ranged from -6.63 to -1.57 . Applying the maximum TU for single pesticides did not significantly change this spectrum. No pesticides were detected in any of the stream bed sediment samples taken in this study, which could reflect too high detection limits and/or an inappropriate sampling technique. More strategic sampling using a stationary suspended sediment sampler is proposed to further optimise the detection success of adsorbed pesticides (Liess et al., 1996). However, Friberg et al. (2003) detected several lipophilic pesticides adsorbed to bed sediments in Danish streams applying a technique similar to the one used in the present study. An additional factor that potentially explains the absence of pesticides in newly deposited bed sediments was the occurrence of several heavy precipitation events during July, which could have reduced the residence time for the pesticides that were adsorbed to fine particulate organic matter.

Nevertheless, the range of TUs measured in this study does have the potential to impair stream ecosystems. Benthic macroinvertebrates have been shown to respond strongly to pesticide contamination (Norum et al., 2010; Rasmussen et al., 2008; Schäfer et al., 2007), and they have successfully been applied as indicator organisms for pesticide contamination in the recently

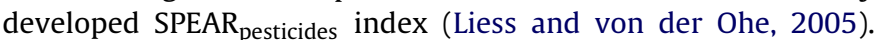

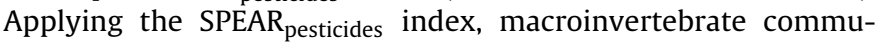
nity changes have been observed at maximum TUs down to -3 in field studies (Schäfer et al., 2011b). The recommended and currently applied threshold value characterising good ecological status in the online SPEAR calculator (33\% SPEcies At Risk) corresponds to a maximum TU value of -3 (see also http://www.systemecology.eu/SPEAR/calculator/index.php?lang= en).

We found that the maximum TU and summed TUs concurrently exceeded the threshold value for ecosystem effects in five streams representing more than $50 \%$ of the streams at risk of being contaminated by agricultural pesticides (proportion of agriculture $\geq 50 \%$ in the stream corridor). Other anthropogenic stressors may be of higher importance than non-point pesticide contamination (Rasmussen et al., 2011), but our results clearly emphasise that non-point source pesticide contamination is a potential problem in small Danish streams. Not surprisingly, the insecticide Pirimicarb represented the primary risk for benthic fauna due to its mode of action, which acts selectively against this group of organisms. Fungicides having a less specific mode of action were, additionally, relevant stressors for the benthic macroinvertebrates. Our findings are congruently supported by a large body of evidence that identifies insecticides and fungicides as the primary pesticide stressors directly impacting benthic macroinvertebrates in streams (see e.g. Liess et al., 2005; Schäfer et al., 2007, 2011a; Schulz, 2004). In addition, we found that the herbicide, Pendicmethalin (inhibits mitosis), might also act as a potentially important stressor for benthic macroinvertebrates.

\subsection{Implications for stream management and the protection of stream ecosystems}

The regression line in Fig. $2 b$ represents the maximum TU as a function for minimum buffer strip width; $Y=-6.586( \pm 0.681)+6.235( \pm 1.24) \times \exp (-0.249( \pm 0.105) x)$.

Assuming that the relationship is causative, the minimum buffer strip width necessary for obtaining good ecological status (maximum $\mathrm{TU} \leq-3$ ), as required by the European WFD, is $6.6 \mathrm{~m}$. This is strongly contrasted by present legislative requirements in Denmark where only natural streams or streams with a high ecological objective (approximately $40 \%$ of the total stream network) are required to have $2 \mathrm{~m}$ of uncultivated buffer strips. The aim of buffer strips in Denmark is only to protect stream banks from erosion, and pesticide application restrictions are currently enforced only via application guidelines for specific compounds. The vast majority of Danish streams are therefore still unprotected against pesticide contamination. However, considering the large variability in data around the fitted regression and the preceding difficulties in predicting optimal dimensions for the buffer strip retaining capacity, we recommend that the suggested minimum buffer strip width is considered with care. Furthermore, Schäfer et al. (2007) detected very high maximum TUs in small French streams that were flanked by buffer strips exceeding $11 \mathrm{~m}$. This could indicate that the correlation between minimum buffer strip width and the TU obtained in this study is not applicable for general extrapolation in time or space. However, the results of Schäfer et al. (2007) could be confounded by intensive tile-drainage, as tile drains introduce an important transport route underneath the vegetated buffer strips. Only a few authors have attempted to describe the dimensions that buffer strips should have for optimum performance in terms of pesticide retention (Johnson et al., 2007), probably reflecting the numerous highly variable factors influencing pesticide runoff, including timing and volume of rainfall events occurring subsequent to pesticide application, buffer strip vegetation types and growth phases, soil infiltration capacity, soil moisture and runoff velocity (Klöppel et al., 1997; Lacas et al., 2005; Pot et al., 2005). Depending on the site characteristics, climatic conditions and local pesticide application practices, optimal buffer strip width change. As a consequence, buffer strips wider than $6.6 \mathrm{~m}$ could be necessary for sufficient protection of stream ecosystems from pesticide surface runoff, as it has also been found for different phosphorus forms and other pollutants (Hoffmann et al., 2009; Mander, 2005; Uusi-Kämppä, 2005).

\section{Conclusions}

The minimum width of buffer strips in the near upstream area was found to be the most important environmental parameter 
governing measured summed and maximum TUs in Danish streams. This suggests that the prevalence and dimensions for buffer strips currently required by Danish legislation is, in general, far from sufficient in protecting stream ecosystems from non-point source pesticides. Despite the fact that small streams with catchment sizes under $10 \mathrm{~km}^{2}$ are disregarded within the European WFD (European Commission, 2000), we believe it is still essential to protect the upper branches of streams with buffer strips especially since these systems serve as sources for recolonisation to the reaches further downstream (targeted in the WFD). Providing such sources would add some valuable recovery capacity to the stream ecosystems.

Adding a function for minimum buffer strip width to the Runoff Potential (RP) model improved its power to predict summed Toxic Units in the study streams from $46 \%$ to $64 \%$ without changing the slope or intercept of the regression line. This underlines the importance of considering buffer strip dimensions in the near upstream area within the risk assessment procedure. Using high-resolution data (including buffer strip dimensions) the RP model was found to be a useful screening tool for the identification of stream sections at risk for pesticide contamination. However, we suggest that pesticide transport from agricultural catchments to streams via tile drain flow would further improve the predictive power of the model. Future research should address these shortcomings of the model.

\section{Acknowledgements}

This study was financed by the Danish Research Council (grant no. 2104-07-0035) and is part of the RISKPOINT program. The authors greatly acknowledge Rikke Juul Monberg, Uffe Mensberg, Henrik Stenholt and Marlene Venø Skjærbæk for their valuable support during the field campaign. Furthermore, we thank two anonymous reviewers for constructive comments on the manuscript.

\section{Appendix A. Supplementary data}

Supplementary data associated with this article can be found, in the online version, at doi:10.1016/j.ecoleng.2011.08.016.

\section{References}

Anbumozhi, V., Radhakrishnan, J., Yamaji, E., 2005. Impact of buffer zones on water quality. Ecol. Eng. 24, 517-523.

Danish Environmental Protection Agency, 2008. Pesticide Statistics 2009. Orientering fra Miljøstyrelsen nr. 5, Copenhagen (in Danish).

Danish Environmental Protection Agency, 2009. Pesticide statistics 2010. Orientering fra Miljøstyrelsen nr. 6, Copenhagen (in Danish).

European Commission, 22.12.2000. Directive 2000/60/EC of the European Parliament and of the Council of 23 October 2000 Establishing a Framework for Community Action in the Field of Water Policy. Off. J. Eur. Commun. L327, p. 77.

Friberg, N., Lindstrom, M., Kronvang, B., Larsen, S.E., 2003. Macroinvertebrate/sediment relationships along a pesticide gradient in Danish streams. Hydrobiologia 494, 103-110.

Furse, M., Hering, D., Moog, O., Verdonschot, P., Johnson, R.K., Brabec, K., Gritzalis, K., Buffagni, A., Pinto, P., Friberg, N., Murray-Bligh, J., Kokes, J., Alber, R., UsseglioPolatera, P., Haase, P., Sweeting, R., Bis, B., Szoszkiewicz, K., Soszka, H., Springe, G., Sporka, F., Krno, I., 2006. The STAR project: context, objectives and approaches. Hydrobiologia 566, 3-29.

Grant, R., Blicher-Mathiesen, G., Pedersen, L.E., Jensen, P.G., Madsen, I., Hansen, B. Brüsch, W., Thorling, L., 2006. Survailance catchments for the National Monitoring Program. Faglig rapport nr. 640. Danmarks Miljøundersøgelser, Aarhus Universitet, Denmark, p. 121, (In Danish).

Greve, M.H., Greve, M.B., Bøcher, P.K., Balstrøm, T., Madsen, H.B., Krogh, L., 2007. Generating a Danish raster-based topsoil property map combining choropleth maps and point information. Geografisk Tidsskrift 107 (2)

Hoffmann, C.C., Kjaergaard, C., Uusi-Kämppä, J., Hansen, H.C.B., Kronvang, B., 2009. Phosphorus retention in riparian buffers: review of their efficiency. J. Environ. Qual. 38, 1942-1955.

Johnson, T.E., McNair, J.N., Srivastave, P., Hart, D.D., 2007. Stream ecosystem responses to spatially variable land cover: an empirically based model for developing riparian restoration strategies. Freshw. Biol. 52, 680-695.
Klöppel, H., Kördel, W., Stein, B., 1997. Herbicide transport by surface runoff and herbicide retention in a filter strip: rainfall and runoff simulation studies. Chemosphere 35, 129-141.

Kreuger, J., 1998. Pesticides in stream water within an agricultural catchment in southern Sweden, 1990-1996. Sci. Total Environ. 216, 227-251.

Kreuger, J., Brink, N., 1988. Losses of pesticides from agriculture. In: Pesticides: Food and Environmental Implications. Int. Atomic Energy Agency, Vienna, pp. 101-112.

Kronvang, B., Strøm, H.L., Hoffmann, C.C., Laubel, A., Friberg, N., 2004. Subsurface tile drainage loss of modern pesticides: field experiment results. Water Sci. Technol. 49, 139-148.

Lacas, J.G., Voltz, M., Gouy, V., Carluer, N., Gril, J.J., 2005. Using grassed buffer strips to limit pesticide transfer to surface water: a review. Agron. Sustain. Dev. 25, 253-266.

Lewan, E., Kreuger, J., Jarvis, N., 2009. Implications of precipitation patterns and antecedent soil water content for leaching of pesticides from arable land. Agric. Water Manage. 96, 1633-1640.

Liess, M., Schulz, R., Neumann, M., 1996. A method for monitoring pesticides bound to suspended particles in small streams. Chemosphere 32, 1963-1969.

Liess, M., von der Ohe, C., 2005. Analyzing effects of pesticides on invertebrate communities in streams. Environ. Toxicol. Chem. 24, 954-965.

Liess, M., Brown, C., Dohmen, P., Duquesne, S., Hart, A., Heimbach, F., Kreuger, J., Lagadic, L., Maund, S., Reinert, W., Streloke, M., Tarazona, J.V., 2005. Effects of pesticides in the field - EPIF. Setac Press, Brussels, pp. 136.

Linders, J., Mensink, H., Stephenson, G., Wauchope, D., Rache, K., 2000. Foliar interception and retention values after pesticide application: a proposal for standardised values for environmental risk assessment. J. Appl. Chem. 72, 2199-2218.

Mander, U., 2005. Purification processes, ecological functions, planning and design of riparian buffer zones in agricultural watersheds. Ecol. Eng. 24, 421-432.

Neumann, M., Schulz, R., Schäfer, K., Müller, W., Mannheller, W., Liess, M., 2002. The significance of entry routes as point and non-point sources of pesticides in small streams. Water Res. 36, 835-842.

Norum, U., Friberg, N., Jensen, M.R., Pedersen, J.M., Bjerregaard, P., 2010. Behavioral changes in three species of freshwater macroinvertebrates exposed to the pyrethroid lambda-cyhalothrin: laboratory and stream microcosm studies. Aquat. Toxicol. 98, 328-335.

Pot, V., Simunek, J., Benoit, P., Coquet, Y., Yra, A., Martinez-Cordon, M.J., 2005. Impact of rainfall intensity on the transport of two herbicides in undisturbed grassed filter strip soil cores. J. Contam. Hydrol. 81, 63-88.

Probst, M., Berenzen, N., Lentzen-Godding, A., Schulz, R., Liess, M., 2005. Linking land use variables and invertebrate taxon richness in small and medium-sized agricultural streams on a landscape level. Ecotoxicol. Environ. Saf. 60, 140-146.

Rasmussen, J.J., Friberg, N., Larsen, S.E., 2008. Impact of Lambda-cyhalothrin on a macroinvertebrate assemblage in outdoor experimental channels: implications for ecoystem functioning. Aquat. Toxicol. 90, 228-234.

Rasmussen, J.J., Baattrup-Pedersen, A., Larsen, S.E., Kronvang, B., 2011. Local physical habitat quality clouds the effect of predicted pesticide runoff from agricultural land in Danish streams. J. Environ. Monit. 13, 943-950.

Renaud, F.G., Brown, C.D., 2008. Simulating pesticides in ditches to assess ecological risk (SPIDER): II. Benchmarking for the drainage model. Sci. Total Environ. 394, 124-133.

Schäfer, R.B., Caquet, T., Siimes, K., Mueller, R., Lagadic, L., Liess, M., 2007. Effects of pesticides on community structure and ecosystem functions in agricultural streams of three biogeographical regions in Europe. Sci. Total Environ. 382, 272-285.

Schäfer, R.B., Pettigrove, V., Rose, G. Allinson, G. Withtwick, A von der Ohe, P.C. Shimeta, J., Kühne, R., Kefford, B.J., 2011a. Effects of pesticides monitored with three sampling methods in 24 sites on macroinvertebrates and microorganisms. Environ. Sci. Technol. 45, 1665-1672.

Schäfer, R.B., van den Brink, P.J., Liess, M., 2011b. Impacts of pesticides on freshwater ecosystems. In: Sanchez-Bayo, F., van den Brink, P..., Mann, R.M. (Eds.), Ecological Impacts of Toxic Chemicals. Bentham:Bussum, The Netherlands.

Schulz, R., 2004. Field studies on exposure, effects, and risk mitigation of aquatic nonpoint-source insecticide pollution: a review. J. Environ. Qual. 33, 419-448.

Schriever, C.A., von der Ohe, C., Liess, M., 2007a. Estimating pesticide runoff in small streams. Chemosphere 68, 2161-2171.

Schriever, C.A., Ball, M.H., Holmes, C., Maund, S., Liess, M., 2007b. Agricultural intensity and landscape structure: influence on the macroinvertebrate assemblages of small streams in Germany. Environ. Toxicol. Chem. 26, 346-357.

Thomas, D.S.G., Goudie, A., 2000. The Dictionary of Physical Geography, 3rd edn. Blackwell Publishing Ltd.

Tomlin, C.D.S., 2001. The Pesticide Manual, A World Compendium. Crop Protection Publications, Farnham, Surrey, UK.

Uusi-Kämppä, J., 2005. Phosphorus purification in buffer zones in cold climates. Ecol. Eng. 24, 491-502.

Vidon, P., Allan, C., Burns, D., Duval, T.P., Gurwick, N., Inamdar, S., Lowrance, R., Scott, D., Sebestyen, S., 2010. Hot spots and hot moments in riparian zones: potential for improved water quality management. J. Am. Water Res. Assoc. 46, 278-298.

Warne, M.S.J., Hawker, D.W. 1995. The number of components in a mixture determines whether synergistic and antagonistic or additive toxicity predominate: the Funnel hypothesis. Ecotoxicol. Environ. Saf. 31, 23-28.

Wauchope, R.D., 1978. The pesticide content of surface water draining from agricultural fields - a review. J. Environ. Qual. 7, 459-472. 